\title{
Genomic characteristics of Staphylococcus aureus strains associated with high within-herd prevalence of intramammary infections in dairy cows
}

\author{
P. Cremonesi, ${ }^{*}$ F. Pozzi,† M. Raschetti, ${ }^{*}$ G. Bignoli, ${ }^{*}$ E. Capra, ${ }^{*}$ H. U. Graber,ł F. Vezzoli,† R. Piccinini,§ \\ B. Bertasi,\# S. Biffani, ${ }^{*}$ I B. Castiglioni, ${ }^{*}$ and M. Luini ${ }^{1}$ \\ *Istituto di Biologia e Biotecnologia Agraria, CNR, via Einstein, 26900 Lodi, Italy \\ †Istituto Zooprofilattico Sperimentale della Lombardia e dell'Emilia, Sezione di Lodi, via Einstein, 26900 Lodi, Italy \\ $\ddagger$ Agroscope, Institute for Food Sciences (IFS), Schwarzenburgstrasse 161, CH-3003, Bern, Switzerland \\ §Dipartimento di Scienze Veterinarie e Sanità Pubblica, Università degli Studi di Milano, via Celoria, 20133 Milan, Italy \\ \#lstituto Zooprofilattico Sperimentale della Lombardia e dell'Emilia, Reparto Tecnologie Acidi Nucleici Applicate agli Alimenti, via Bianchi, \\ 25124 Brescia, Italy \\ IIParco Tecnologico Padano, Via Einstein, 26900 Lodi, Italy
}

\section{ABSTRACT}

Staphylococcus aureus is one of the most important causes of mastitis in dairy cattle. Based on previous research, Staph. aureus genotypes with different pathogenic and contagious properties can cause intramammary infection (IMI) and coexist in the same herd. Our study aimed to compare Staph. aureus strains from herds that differed in IMI prevalence using different molecular approaches such as ribosomal spacer (RS)PCR, multilocus sequence typing (MLST), spa typing, ribotyping, pulsed-field gel electrophoresis (PFGE), and multiplex PCR. For this purpose, 31 dairy herds with Staph. aureus IMI were selected, and 16 of these were chosen for a comparison study: the 8 high-prevalence (HP) herds had Staph. aureus IMI prevalence $>28 \%$ and the 8 low-prevalence (LP) herds had an IMI prevalence $<4 \%$. A total of 650 isolates of Staph. aureus from mammary quarters of all positive cows were genotyped with RS-PCR, a technique based on amplification of a portion of the intergenic spacer 16S-23S rRNA, and a subset of 54 strains was also analyzed by multiplex PCR, ribotyping, PFGE, MLST, and spa typing. The RS-PCR analysis revealed 12 different profiles. Staphylococcus aureus strains isolated from 5 out of 8 HP herds showed a profile identical to the genotype B (GTB), described in previous studies as being strongly associated with high within-herd prevalence of Staph. aureus mastitis and the presence of the genes coding for enterotoxins sea, sed, and $s e j$, a long x-region of spa gene, and 3 lukE fragments. Moreover, all strains isolated in the HP herds possessed genes coding for staphylococcal enterotoxins. In LP herds, a limited number of strains of 6 genotypes, different from those isolated

Received November 5, 2014.

Accepted June 9, 2015.

${ }^{1}$ Corresponding author: mariovittorio.luini@izsler.it in HP herds, were identified and GTB was not found. Within these genotypes, 4 strains were positive for the mecA gene. Preliminary results and comparison with other genotyping methods confirmed that genotyping by RS-PCR is an accurate, rapid, and inexpensive tool for future field studies on Staph. aureus mastitis strains and generates clinically relevant results.

Key words: Staphylococcus aureus, mastitis, genotyping, virulence gene

\section{INTRODUCTION}

Staphylococcus aureus is one of the most important causes of both contagious and chronic mastitis in dairy cattle. It affects both milk production and milk quality, leading to relevant losses in the dairy industry (Hogeveen et al., 2011). As described by many researchers (Joo et al., 2001; van Leeuwen et al., 2005; Zecconi et al., 2005), the Staph. aureus IMI pattern can vary across herds, depending on strain differences. Indeed, this microorganism is able to produce a large number of extracellular factors, including membrane-damaging toxins (such as $\beta$-toxin), epidermolytic toxin (eta, etb), toxic shock syndrome toxin (tsst), exoenzymes (coagulase and thermonuclease), and staphylococcal enterotoxins. The severity of the pathology might be linked to the production of a single or multiple virulence factors that enhance the virulence of producing strains.

Genotyping of Staph. aureus isolated from bovine milk is an important tool in epidemiological studies of mastitis and contributes to our understanding of the pathogen's dissemination (Castelani et al., 2013). As shown by a variety of strain-typing methods (Smith et al., 2005; Fournier et al., 2008; Graber et al., 2009), in most herds, one predominant strain of Staph. aureus spreads within the herd, due to its pathogenic and contagious properties, but can coexist with several other Staph. aureus strains (Piccinini et al., 2010; Zadoks et 
al., 2000). Strain identification is essential for the correct classification of reservoirs, especially when several Staph. aureus strains occur in the same herd (Sommerhäuser et al., 2003).

In studies attempting to identify Staph. aureus strains associated with IMI in extramammary sites, many researchers (Middleton et al., 2002; Jørgensen et al., 2005; Haveri et al., 2008; Piccinini et al., 2009) have used pulsed-field gel electrophoresis (PFGE). At the same time, other methods such as binary typing, multilocus sequence typing (MLST), or DNA array have been developed to subtype Staph. aureus. More recently, Fournier et al. (2008) used ribosomal spacer PCR (RS-PCR) for an epidemiological study in Swiss herds located within a small area in Switzerland. The results showed a strong association between genotypes and virulence gene patterns, revealing the predominance of a Staph. aureus genotype B (GTB) profile. This genotype - characterized by the presence of genes coding for sea, sed, and sej enterotoxins, a long x-region of spa, and 3 lukE fragments - revealed a close association with both high within-herd prevalence and high SCC levels (Graber et al., 2009). Based on these findings, we were interested to investigate whether an association between specific genotypes or virulence gene patterns of the strains and high within-herd prevalence of IMI, could also be found in different geographical areas and diverse farming conditions (i.e., larger herds, different breeds). The confirmation of this hypothesis would be of great clinical relevance and might facilitate type-specific hygiene and treatment strategies in affected herds. The objective of the present study was to compare Staph. aureus strains isolated from herds with different IMI prevalence; namely, herds with low and high prevalence of IMI. The isolates were analyzed by different molecular approaches to evaluate specific molecular characteristics associated with infectivity of the circulating strains.

\section{MATERIALS AND METHODS}

\section{Study Design and Herd Selection}

Between September 2011 and August 2012, 31 dairy cattle herds with the presence of Staph. aureus IMI but the absence of other contagious microorganisms, such as Streptococcus agalactiae and Mycoplasma bovis, were selected for this study. Bacteriological analyses had been previously performed at the regional public health veterinary laboratories (Istituto Zooprofilattico Sperimentale della Lombardia e dell'Emilia Romagna, IZSLER). The average size of the herds was 106 milking cows (range 38 to 285 cows); all farms reared Hol- stein Friesian cattle and were located in the Lombardy region of northern Italy.

To select a definitive number of the herds for a comparative study, we initially determined the Staph. aureus IMI prevalence on the farms using bacteriological examination of composite milk samples collected cow by cow (first sampling). Then, based on the results of this first sampling, 16 herds were selected overall: 8 herds with the highest prevalence (HP) of Staph. aureus IMI and 8 with the lowest prevalence $(\mathbf{L P})$. The Staph. aureus-positive cows were subsequently resampled 1 to 3 wk later by individual quarters to detect infected quarters and perform the molecular characterization of the isolates. Finally, the proportions of (1) Staph. aureus-infected cows, (2) infected quarters, and (3) cows with more than one infected quarter were determined as indicators of strain infectivity.

The LP and HP herds were also investigated to evaluate a specific indicator of milking routine such as teatend hyperkeratosis and a specific risk factor for IMI prevalence such as lactation number $(\mathbf{L N})$. Parity and teat-end hyperkeratosis of lactating cows are considered risk factors for transmission and, consequently, for within-herd prevalence of Staph. aureus IMI (Zadoks et al., 2000; Graber et al., 2009). These factors might affect IMI prevalence, leading to biased conclusions regarding the contagious properties of the different Staph. aureus strains analyzed. Based on these findings, both LN and teat condition score (TCS) were recorded for each sampled cow. Parity information was obtained by the Regional Breeders' Association (ARAL, Crema, Italy), as a categorical variable (LN) with 4 levels: the first 3 levels corresponded to first, second, and third parities, respectively, and the fourth level included parities $\geq 4$.

Teat condition score was evaluated visually for each cow during milk sampling and assigned using the methodology proposed by Neijenhuis et al., (2000): a smooth callous ring around the orifice was evaluated as TCS = 2 ; a rough and very rough callous ring were evaluated as TCS $=3$ and 4 , respectively. Subsequently, the average TCS for each cow was calculated as the arithmetic mean of the 4 individual teat scores and finally, the average TCS was grouped in binary classes based on the cutoff value of 3 : if the average TCS $\geq 3$, the TCS class was coded as "rough," and "normal" otherwise.

\section{Sample Collection and Bacteriological Analyses}

All milk samples were collected aseptically. Samples were kept at $4^{\circ} \mathrm{C}$ and bacteriological assays were performed within $48 \mathrm{~h}$. Milk samples were cultured with standard methods by plating approximately $10 \mu \mathrm{L}$ on esculin agar blood plates and Baird Parker with rabbit 
plasma fibrinogen agar (BP-RPF). After incubation at $37^{\circ} \mathrm{C}$ for $48 \mathrm{~h}$, suspected colonies (hemolytic or those developing the typical halo on BP-RPF), were confirmed by tube coagulase test and by a specific PCR assay targeting the nuc gene (Cremonesi et al., 2005). The growth of one colony in $10 \mu \mathrm{L}$ of inoculated milk $(100 \mathrm{cfu} / \mathrm{mL})$ was chosen as the threshold to define a mammary quarter as infected, as suggested by Dohoo et al., (2011).

\section{Molecular Analysis}

All isolates from HP and LP herds were subjected to DNA extraction and genotyped by RS-PCR analysis. Based on the results of the RS-PCR, 3 or 5 strains for each different genotype from the LP and HP herds were randomly selected according to the number of the infected quarters (fewer or more than 50, respectively) found in each herd analyzed. This subset of strains was analyzed with a deeper molecular characterization using (1) multiplex PCR targets for genes encoding enterotoxins and other virulence genes such as leukocidins and leukotoxins, (2) ribotyping, (3) PFGE, (4) MLST, and (5) spa typing.

DNA Extraction. DNA was extracted from strains using the protocol described by Cremonesi et al. (2006). The amount and quality of DNA were measured using a NanoDrop ND-1000 spectrophotometer (Nano-Drop Technologies, Wilmington, DE), and DNA was stored at $-20^{\circ} \mathrm{C}$ until use.

$\boldsymbol{R} \boldsymbol{S}$-PCR Analysis. The method of Fournier et al. (2008), based on the amplification of the 16S-23S rRNA intergenic spacer region, was used for RS-PCR genotyping. Genotypes were defined according to Fournier et al. (2008), improved by calculating the corresponding Mahalanobis distance of informative peak sizes, and by comparing it to those of the prototype strains using the "Mahalanobis Distances of Staph. aureus Genotypes" software (Syring et al., 2012).

Multiplex PCR for Virulence Factors. The DNA was amplified to verify the presence of virulenceassociated genes using primers and protocols described previously [sea, sec, sed, seg, seh, sei, sej, sek, and sel (Cremonesi et al., 2005); seb and see (Monday and Bohach, 1999; Pinto et al., 2005); coa, clfA, spa, tsst, eta, and etb (Akineden et al., 2001); LukE (Fournier et al., 2008); $L u k S-L u k F / P V$ and mecA (McClure et al. 2006); sak, fmtB, scn, and chp (Sung et al., 2008); LukE-LukD and LukM (Jarraud et al., 2002); and cna (Zecconi et al., 2006)]. The amplified PCR fragments were distinguished by $2 \%$ agarose gel electrophoresis (GellyPhor, Euroclone, Milan, Italy), stained with ethidium bromide $(0.05 \mathrm{mg} / \mathrm{mL}$; Sigma Aldrich, Mi- lan, Italy), and visualized by a UV transilluminator (BioView Ltd., Nes Ziona, Israel). A 100-bp DNA ladder (Finnzymes, Espoo, Finland) was included in each gel electrophoresis.

Ribotyping. The strains were analyzed using the RiboPrinter (DuPont Qualicon, Wilmington, DE), an automated ribotyping system, following the manufacturer's operating instructions. Similarities between restriction endonuclease digestion profiles were analyzed using BioNumerics software (Applied Maths, Kortrijk, Belgium). Clustering was evaluated by the unweighted pair group method with arithmetic mean (UPGMA).

$\boldsymbol{P F G E}$. Strain differentiation of Staph. aureus isolates was done by PFGE of digested DNA using a CHEF mapper system (Bio-Rad Laboratories, Hercules, CA) with the procedure described by Jorgensen et al. (2005). The CHEF mapper system was used to separate DNA fragments, and band patterns were analyzed using BioNumerics software (version 6.6, Applied Maths, Ghent, Belgium). The Dice coefficient and UPGMA with $1 \%$ tolerance enabled construction of dendrograms to establish similarities between strains.

MLST. Internal PCR fragments of 7 housekeeping genes were amplified using previously described primers and protocols (Enright et al., 2000). Clonal analysis of the sequence types (ST) was performed using e-BURST, a web-implemented clustering algorithm (http://www.mlst.net; http://eburst.mlst.net), which divides MLST data sets into groups of related isolates and predicts the founding genotype of each clonal complex (CC). Sequence types with at least 5 of 7 identical alleles were defined as a clonal group.

spa Typing. The spa typing analysis was done using the protocol described by Shopsin and coworkers (1999). The spa types were assigned through the Ridom SpaServer (http://www.spaserver.ridom.de).

\section{Statistical Analysis}

A multiple logistic regression model was used to test the hypothesis that the evaluated risk factors (TCS and LN) did not differ between HP and LP herds. Teat condition score (2 classes) and LN (4 classes) were analyzed in a model in which the cow was the experimental unit and herd type (LP or HP) the dependent variable. In this model, the logit(.) was the link function between the probability for a cow to belong to either a LP or HP herd and the risk factors TCS and LN. The random sire effect was added to the right-hand side of the model to take into account the covariance existing between daughters of the same sire. The concordance Simpson's index of diversity was calculated to measure the discriminatory power of RS-PCR, spa typing, MLST, 
ribotyping, and PFGE. This index indicates the probability that 2 strains sampled randomly from a population will belong to 2 different types (Hunter, 1990) and ideally, it should be equal to 1.0. The Simpson function from the R package untb (Hankin, 2007) was used to estimate Simpson's index.

\section{RESULTS}

\section{Bacteriological Analysis}

In the first sampling (31 herds), 3,311 cows were sampled overall and bacteriological analysis revealed a Staph. aureus herd prevalence ranging from 0.7 to $62 \%$. Specifically, Staph. aureus prevalence in the 16 herds selected for this comparative study ranged from 0.7 to $6 \%$ and from 28 to $62 \%$ for LP and HP herds, respectively. Because some cows were slaughtered and other cows were dried off between the first and second samplings, as reported in Table 1, 361 positive cows were resampled overall, 23 of 28 and 338 of 366 in LP and HP herds, respectively. A total of 1,322 quarters were considered in the second sampling. Almost all of the 361 resampled cows tested positive for at least one quarter (21 out of 23 and 338 out of 338 in LP and HP herds, respectively). In LP and HP herds, 24 (26.9\%) and $626(47.3 \%)$ quarters were positive, respectively, and 650 Staph. aureus isolates were collected (Table $1)$. The average proportion of infected cows with more than one infected quarter was $23.8 \%$ (5 of 21) and $55.0 \%$ (186 of 338) in LP and HP herds, respectively. This difference was statistically significant according to Chi-squared test $(P<0.01)$.

\section{Molecular Analysis}

The RS-PCR genotyping analysis of the 650 isolates revealed the presence of 12 different profiles (Table 1 ). The analysis of the profiles circulating in LP herds, performed with the dedicated software, generated the following genotypes: GTS, GTR and its variant GTR, GTC, and GTBE. Among them, GTS was the most frequent -it was detected in 4 of 8 herds analyzed. Except for 1 herd (herd 27, Table 1) in which 2 genotypes coexisted, there was only 1 Staph. aureus strain circulating in each of the remaining LP herds. In HP herds, RS-PCR analyses showed the presence of genotype GTB and its variant $\mathrm{GTB}^{\mathrm{I}}$, GTK, GTR ${ }^{\mathrm{VI}}$, GTAQ, GTBT, and GTBM. All quarters of a cow were infected with the same genotype. Genotype B was the most common genotype - it was detected in 5 of 8 herds, in $412(65.8 \%)$ of the 626 Staph. aureus-positive quarters analyzed. In 2 of these GTB-infected herds, we also found 1 variant strain $\mathrm{GTB}^{\mathrm{I}}$ (herd 23) and 1 GTAQ

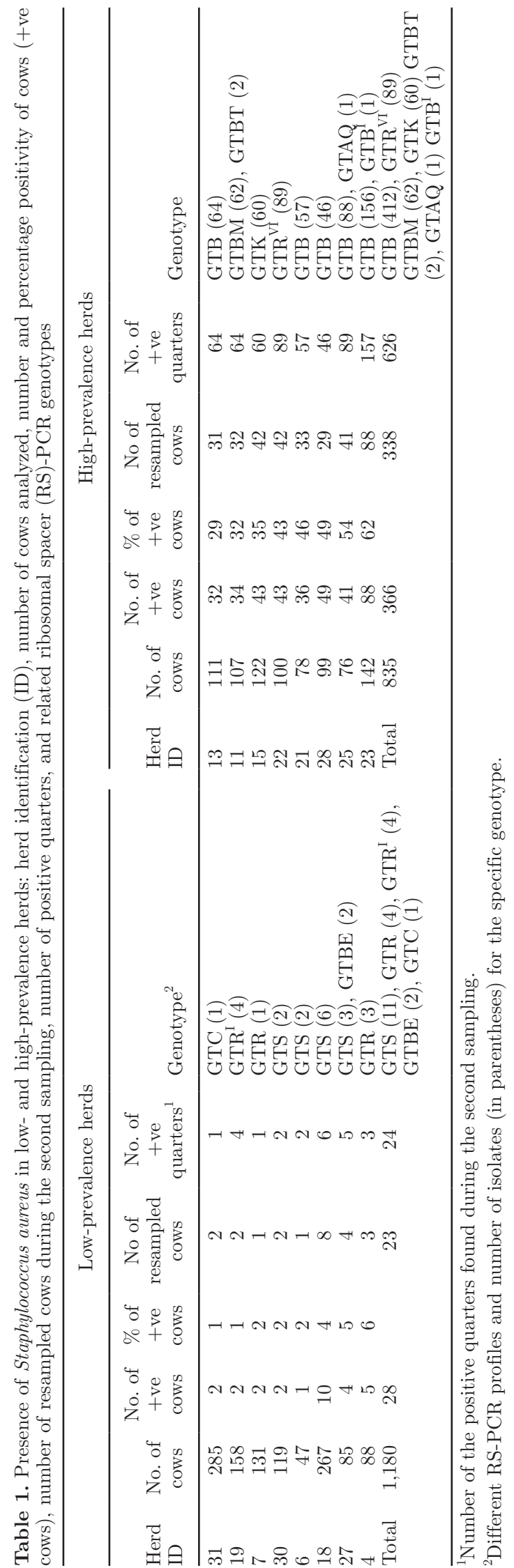

Journal of Dairy Science Vol. 98 No. 10, 2015 
(herd 25) genotype. In the remaining 3 HP herds, the GTK, GTR ${ }^{\mathrm{VI}}$, and GTBM genotypes were found. Genotype GTBM (a total of 62 isolates) was found to be predominant in herd 11, and 2 additional isolates were also found to belong to GTBT in this herd.

\section{Additional Molecular Analyses}

Based on the results of RS-PCR, a subset of 54 strains representative of LP and HP isolates was analyzed with additional techniques. All different RS-PCR genotypes detected in the herds undergoing this study were represented in this subset.

Ribotyping and PFGE. The subset of 54 Staph. aureus isolates were genotyped by ribotyping and PFGE (Figures 1 and 2). Because defining clonality in PFGE using a similarity value of $80 \%$ as a cut-off is considered the gold standard (McDougal et al., 2003), we used this cut-off value of $80 \%$ for both PFGE and ribotyping. By PFGE and ribotyping, the isolates were grouped into 13 pulsotypes or 7 ribotypes, respectively. The GTB and GTS isolates were grouped in 2 different clusters by both ribotyping and PFGE. The GTK profile, which included 3 isolates at the $80 \%$ cut-off value, was divided into 3 different ribotypes.

MLST. Using MLST, the subset of 54 strains were grouped in 7 and 5 different ST for LP and HP herds, respectively (Table 2). The most common ST were ST398 (9 isolates, 16.4\%) from LP herds and ST8 (21 isolates, $38.2 \%$ ) from HP herds. All strains belonging to CC8-ST8 were classified by RS-PCR as GTB, whereas CC398-ST398 corresponded to GTS. The MLST data analysis by eBURST grouped the isolates into CC522, CC5, CC398, CC133, CC705, and CC97 for LP herds, and into $\mathrm{CC} 8, \mathrm{CC} 126, \mathrm{CC} 5, \mathrm{CC} 97$, and $\mathrm{CC} 1$ for $\mathrm{HP}$ herds.

spa Typing. As described in Table 2, spa typing revealed the presence of 7 spa types in LP herds and 11 spa types in HP herds. Six new spa types - t14155, t14153, t14169, t14218, t14171, and t14172-were also identified.

Multiplex PCR for Virulence Factors. All 54 strains were positive for lukE, cna, and lukD genes and negative for other virulence factors such as tsst, eta, $e t b$, seb, and see. As described in Table 2, all strains isolated from HP herds and strains isolated from 4 out of $8 \mathrm{LP}$ herds harbored 2 or more genes coding for different enterotoxins, with $65.4 \%$ of isolates carrying sea, sed, and sej and $9 \%$ of strains carrying sed and sej. Four strains from 2 different LP herds were positive for the mecA gene, and 3 of these were positive for 2 or more enterotoxins (Table 2). The strains collected in 7 out of 8 LP herds carried LukM, whereas all HP strains were negative for this target. For the remaining genes, no difference could be demonstrated between isolates from LP and HP herds. Analysis of the spa region and the coa gene produced amplicons of different sizes, as summarized in Table 2.

\section{Statistical Analysis}

Cows from LP and HP herds did not differ in terms of LN, TCS, or their interaction. The average LN was 2.29 (maximum parity $=8$ ) and 2.21 (maximum parity $=8$ ) for LP and HP herds, respectively. The average frequencies of normal and rough teat scores, respectively, were 96.3 and $3.7 \%$ in LP herds and 99.3 and $0.7 \%$ in HP herds. Results from logistic regression did not show any significant difference in terms of those risk factors. To compare discriminatory power (Simpson's index of discrimination, D) of RS-PCR, PFGE, MLST, ribotyping and spa typing, we identified the mean number of isolates per type and Simpson's diversity index for all the isolates. The RS-PCR, PFGE, MLST, ribotyping, and spa typing yielded D-values of $0.8236,0.8943,0.8081,0.837$, and 0.9192 , respectively. As shown by Simpson's diversity index in our study, RS-PCR showed discriminatory power similar to the other more-recognized genotyping methods. This finding is consistent with the findings of a previous study (Fournier et al., 2008).

\section{DISCUSSION}

Using different genotyping techniques, we analyzed isolates from herds with low and high Staph. aureus IMI prevalence. The results obtained by RS-PCR confirmed previous findings that different Staph. aureus genotypes with specific epidemiological properties circulate through dairy herds (Graber et al., 2009; Piccinini et al., 2010). It is important to note that all genotypes, sequence types, and spa types of the isolates were completely different between the HP and LP herds, confirming that particular genotypes or virulence profiles could be associated with diverse clinical outcomes, especially with the prevalence of IMI. In our study, GTB (ST8) appears to be closely associated with high within-herd prevalence of IMI as described in previous works based on field data (Graber et al., 2009; Voelk et al., 2014), whereas genotypes GTS (ST398), GTR ${ }^{\mathrm{I}}$ (ST2111), and GTC (ST151) were related to low within-herd prevalence, showing a limited tendency to spread in the herd. Because a specific indicator of milking routine (TCS) and a specific risk factor for IMI prevalence (LN) did not differ significantly between HP and LP herds, the diverse within-herd Staph. aureus IMI prevalence was 


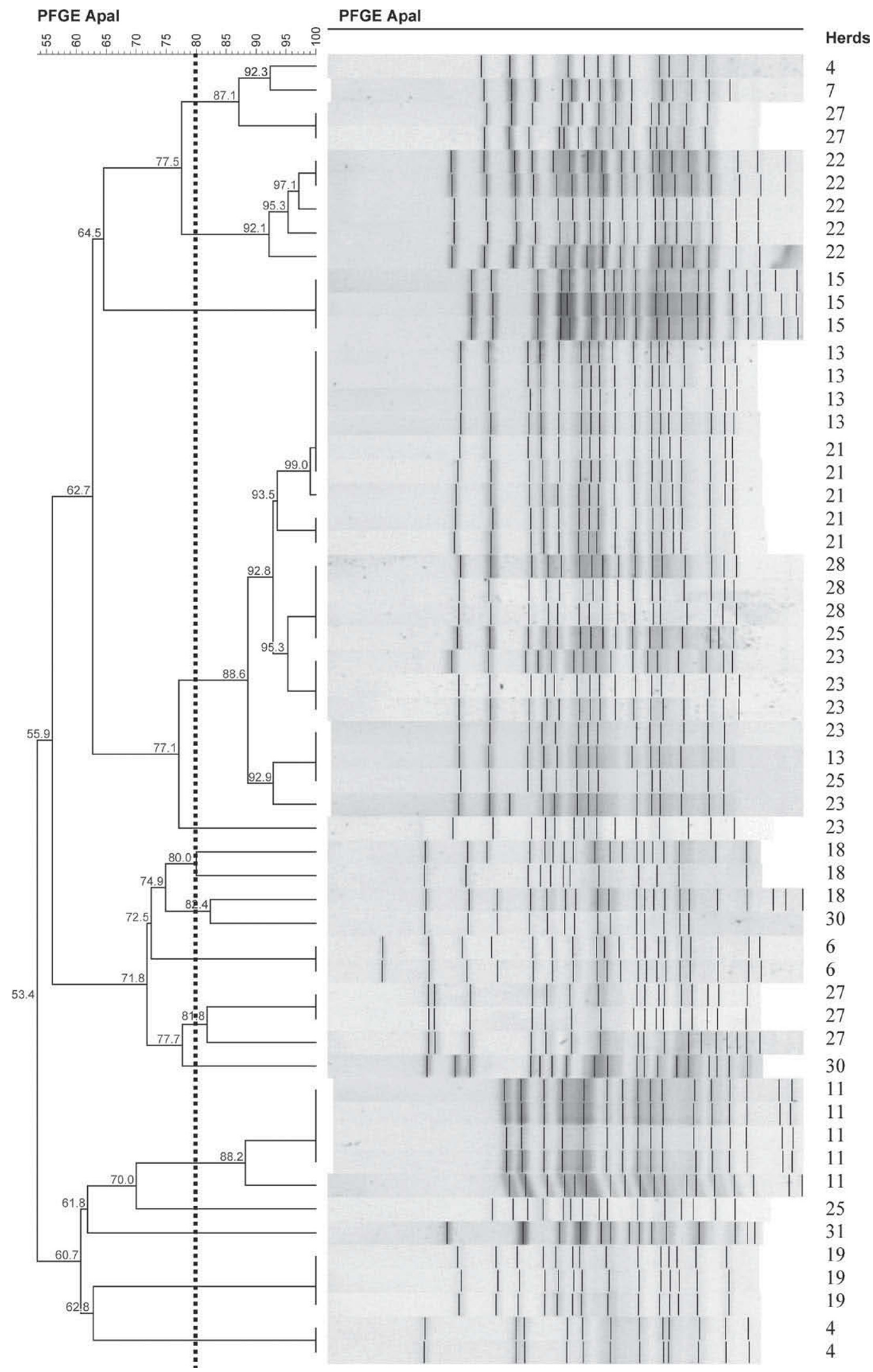

Figure 1. Pulsed-field gel electrophoresis (PFGE using ApaI = restriction enzyme) analysis of the subset of 54 Staphylococcus aureus strains isolated from 8 high-prevalence (HP) and 8 low-prevalence (LP) herds. An $80 \%$ cut-off value was used for the analysis. 


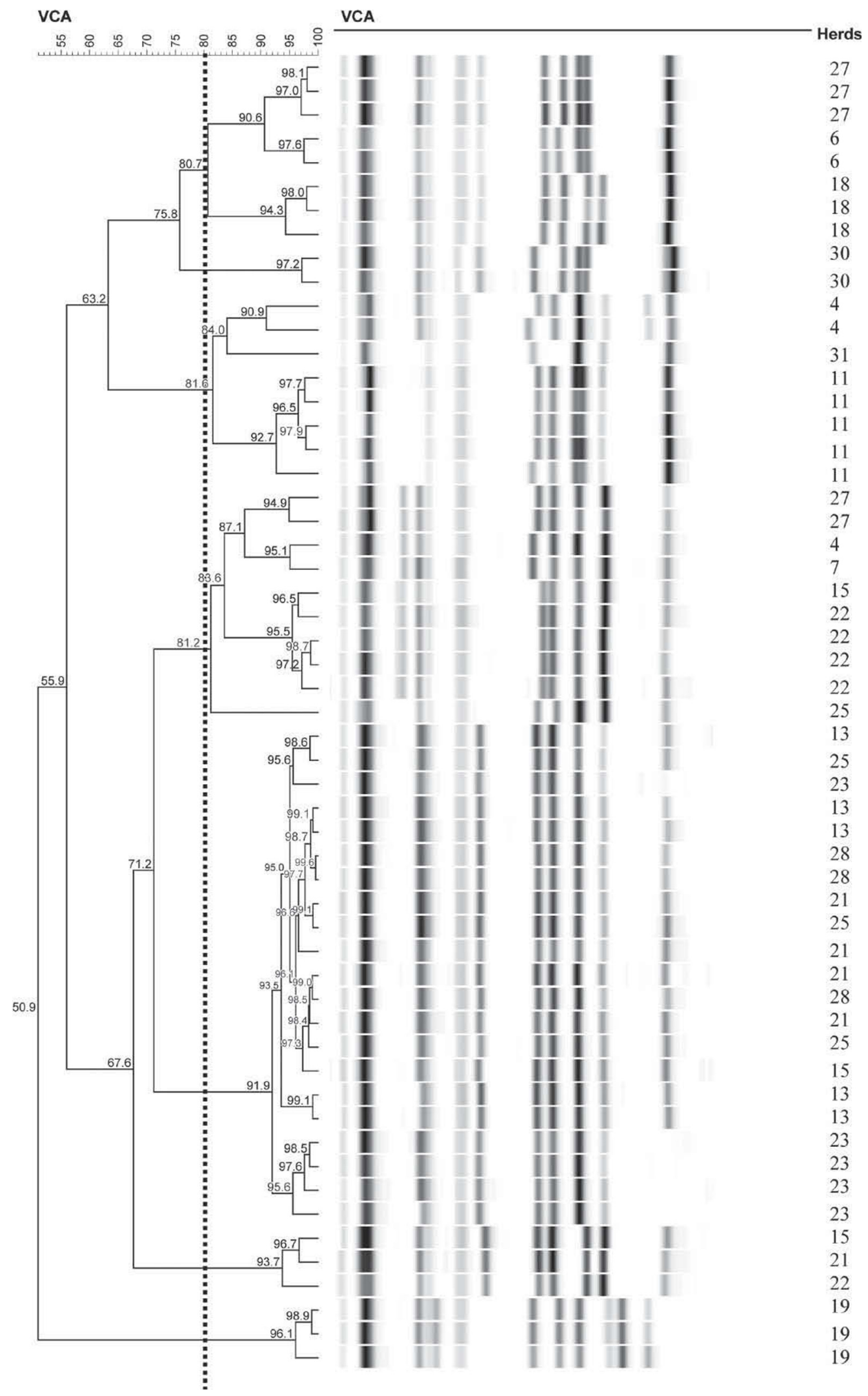

Figure 2. Ribotyping analysis of the subset of 54 Staphylococcus aureus strains isolated from 8 high-prevalence (HP) and 8 low-prevalence (LP) herds. An $80 \%$ cut-off value was used for the analysis. VCA indicates an EcoRI pattern by automated ribotyping. 


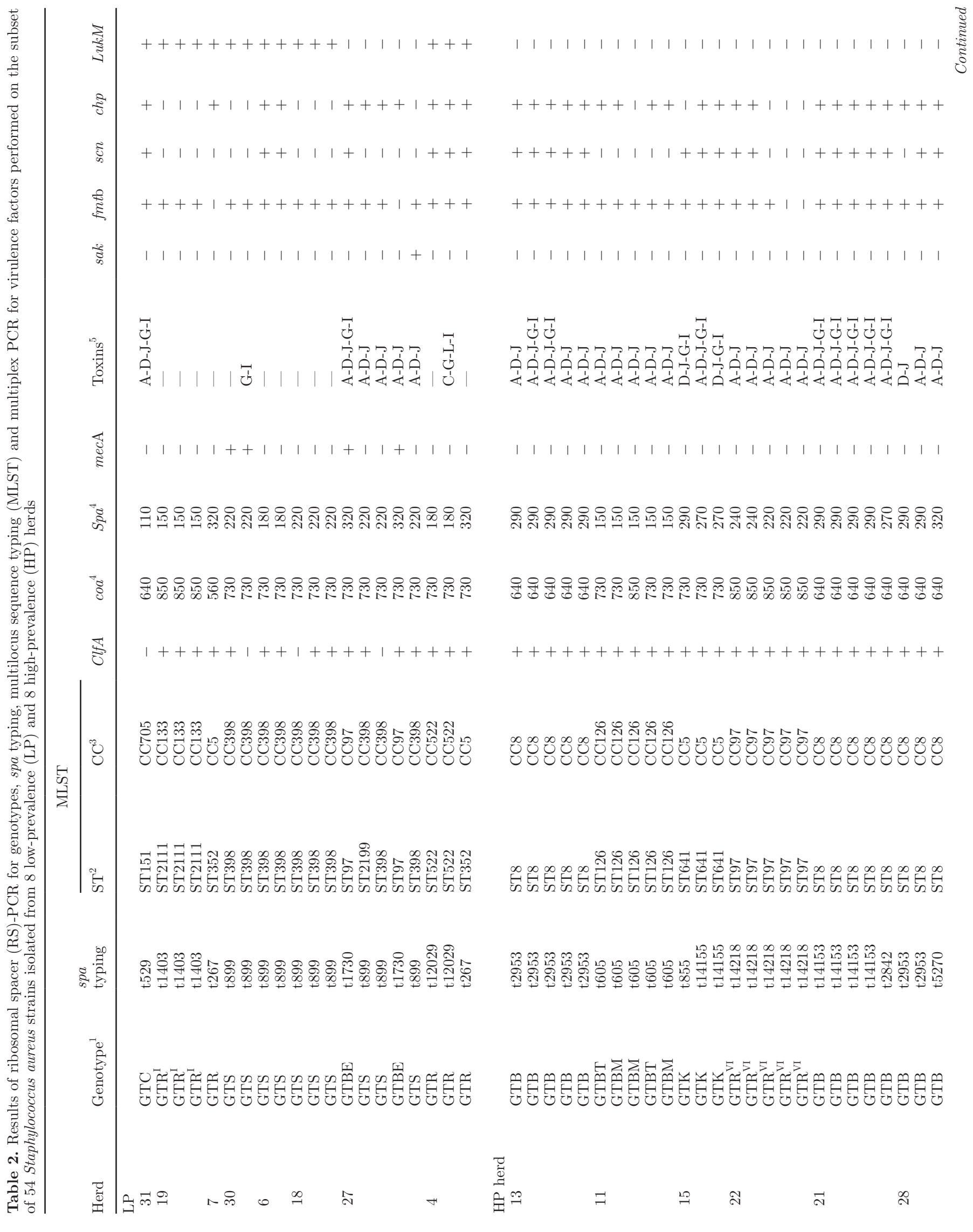


likely a consequence of the different properties of the involved strains.

In the present study, all GTB strains analyzed by MLST (21 samples) were classified as ST8/CC8. Recently, Sakwinska and coworkers (2011) reported that CC8 strains were frequently detected in bovine mastitis, constituting more than one-third of Staph. aureus isolates from western Switzerland. This clonal complex has been described previously both from cases of bovine mastitis (Kozytska et al., 2010; Hata et al., 2010; Johler et al., 2011; Stutz et al., 2011) and from human isolates (Sung et al., 2008), suggesting that a new bovine adaptation took place due to a recent human-to-cow host jump (Resch et al., 2013). Despite the high prevalence of GTB in HP herds, in contrast to Graber et al. (2009), 3 out of 8 herds (herds 11, 15, and 22) revealed the presence of genotypes other than GTB, such as GTBM, GTK, and GTR ${ }^{\mathrm{VI}}$. These genotypes, belonging to $\mathrm{CC} 126$, CC5, and CC97, respectively, also revealed a prevalence as high as that associated with GTB.

As previously described (Graber et al., 2009), GTB is characterized by the presence of the enterotoxin genes sea, sed, and sej, a long x-region of spa, and a coa amplicon of $640 \mathrm{bp}$. In 3 out of 5 HP herds, GTB was also positive for seg and sei. Except for 2 LP herds (herd 31 and herd 27), where strains with an enterotoxin panel similar to GTB were found, nonenterotoxigenic isolates or strains coding for different enterotoxins were detected in the remaining LP herds. Moreover, LukM, a component of a leukocidin gene encoding one operon similar to that of the Panton-Valentine leukocidin (Kaneko and Kamio, 2004), was found in 7 out of 8 LP herds. This finding does not confirm the hypothesis that strains carrying this gene had some advantages in causing IMI at high within-herd prevalence (Schlotter et al., 2012). More likely, the LukM gene is associated with some $\mathrm{CC}$ and not with other, such as CC8, the most prevalent in northern Italy (personal data). In LP herds, we also isolated and analyzed methicillin-resistant Staph. aureus (MRSA). Multilocus sequence typing revealed ST398 (t899) in one herd and ST97 (t1730) in another, belonging to CC398 and CC97, respectively. Clonal complex 97 is quite frequently found in bovine mastitis, but it can also be isolated from human cases (Sung et al., 2008). The MRSA ST398, the prototype clone of livestock-associated MRSA, has been mostly detected in humans in close contact with veal calves and pigs, such as veterinarians or farmers (van Cleef et al., 2011). Despite the scarce information about the clinical outcome of MRSA in cattle, our results confirm the evidence of other personal observations and other studies (Juhász-Kaszanyitzky et al., 2007; Moon et al., 2007; Hendriksen et al., 2008) in which MRSA is more 
likely associated with sporadic mammary infections than with severe contagious IMI.

Overall, among the 29 different genes detected and analyzed by the multiplex PCR (enterotoxins, leukocidins, exfoliatins, and polymorphic genes), we were not able to show that a single gene, group of genes, or cumulative number of different genes was unequivocally responsible for a given infection outcome. However, this study shows that RS-PCR, which is an accurate, rapid, and inexpensive tool, can be successfully used to characterize Staph. aureus strains of bovine mammary origin and can generate results similar to those obtained from different genotyping methods: PFGE, MLST, ribotyping, and spa typing. The findings obtained in this comparative study confirm that GTB is very likely associated with highly contagious properties of Staph. aureus strains.

\section{ACKNOWLEDGMENTS}

This research was supported by the Lombardy Region: Project N. 1745-MASTFIELD "Applicazione di sistemi molecolari innovativi per il controllo in campo delle mastiti bovine." The authors thank the agronomists and veterinarians involved in this project for their important contributions in sampling milk and recording management scores: Lucio Zanini, Rosangela Garlappi, Carla Cattaneo, Giorgio Oldani (ARAL, Associazione Regionale Allevatori Lombardia, Italy).

\section{REFERENCES}

Akineden, O., C. Annemüller, A. A. Hassan, C. Lämmler, W. Wolter, and M. Zschöck. 2001. Toxin genes and other characteristics of Staphylococcus aureus isolates from milk of cows with mastitis. Clin. Diagn. Lab. Immunol. 8:959-964.

Castelani, L., A. F. Santos, M. Dos Santos Miranda, L. F. Zafalon, C. R. Pozzi, and J. R. Arcaro. 2013. Molecular typing of mastitiscausing Staphylococcus aureus isolated from heifers and cows. Int. J. Mol. Sci. 14:4326-4333.

Cremonesi, P., B. Castiglioni, G. Malferrari, I. Biunno, C. Vimercati, P. Moroni, S. Morandi, and M. Luzzana. 2006. Technical note: Improved method for rapid DNA extraction of mastitis pathogens directly from milk. J. Dairy Sci. 89:163-169.

Cremonesi, P., M. Luzzana, M. Brasca, S. Morandi, R. Lodi, C. Vimercati, D. Agnellini, G. Caramenti, P. Moroni, and B. Castiglioni. 2005. Development of a multiplex PCR assay for the identification of Staphylococcus aureus enterotoxigenic strains isolated from milk and dairy products. Mol. Cell. Probes 19:299-305.

Dohoo, I. R., J. Smith, S. Andersen, D. F. Kelton, and S. Godden. 2011. Diagnosing intramammary infections: evaluation of definitions based on a single milk sample. J. Dairy Sci. 94:250-261.

Enright, M. C., N. P. Day, C. E. Davies, S. J. Peacock, and B. G. Spratt. 2000. Multilocus sequence typing for characterization of methicillin-resistant and methicillin-susceptible clones of Staphylococcus aureus. J. Clin. Microbiol. 38:1008-1015.

Fournier, C., P. Kuhnert, J. Frey, R. Miserez, M. Kirchhofer, T. Kaufmann, A. Steiner, and H. U. Graber. 2008. Bovine Staphylococcus aureus: association of virulence genes, genotypes and clinical outcome. Res. Vet. Sci. 85:439-448.
Graber, H. U., J. Naskova, E. Studer, T. Kaufmann, M. Kirchhofer, M. Brechbühl, W. Schaeren, A. Steiner, and C. Fournier. 2009. Mastitis-related subtypes of bovine Staphylococcus aureus are characterized by different clinical properties. J. Dairy Sci. 92:1442-1451.

Hankin, R. K. S. 2007. Introducing untb, an R package for simulating ecological drift under the unified neutral theory of biodiversity. J. Stat. Softw. 22:1-15

Hata, E., K. Katsuda, H. Kobayashi, I. Uchida, K. Tanaka, and M. Eguchi. 2010. Genetic variation among Staphylococcus aureus strains from bovine milk and their relevance to methicillin-resistant isolates from humans. J. Clin. Microbiol. 48:2130-2139.

Haveri, M., M. Hovinen, A. Roslöf, and S. Pyörälä. 2008. Molecular types and genetic profiles of Staphylococcus aureus strains isolated from bovine intramammary infections and extramammary sites. J. Clin. Microbiol. 46:3728-3735.

Hendriksen, R. S., D. J. Mevius, A. Schroeter, C. Teale, D. Meunier, P. Butaye, A. Franco, A. Utinane, A. Amado, M. Moreno, C. Greko, K. Stärk, C. Berghold, A. L. Myllyniemi, D. Wasyl, M. Sunde, and F. M. Aarestrup. 2008. Prevalence of antimicrobial resistance among bacterial pathogens isolated from cattle in different European countries: 2002-2004. Acta Vet. Scand. 50:28.

Hogeveen, H., K. Huijps, and T. Lam. 2011. Economic aspects of mastitis: New developments. N. Z. Vet. J. 59:16-23.

Hunter, P. R. 1990. Reproducibility and indices of discriminatory power of microbial typing methods. J. Clin. Microbiol. 28:1903-1905.

Jarraud, S., C. Mougel, J. Thioulouse, G. Lina, H. Meugnier, F. Forey, X. Nesme, J. Etienne, and F. Vandenesch. 2002. Relationships between Staphylococcus aureus genetic background, virulence factors, agr groups (alleles), and human disease. Infect. Immun. 70:631-641.

Johler, S., F. Layer, and R. Stephan. 2011. Comparison of virulence and antibiotic resistance genes of food poisoning outbreak isolates of Staphylococcus aureus with isolates obtained from bovine mastitis milk and pig carcasses. J. Food Prot. 74:1852-1859.

Joo, Y. S., L. K. Fox, W. C. Davis, G. A. Bohach, and Y. H. Park. 2001. Staphylococcus aureus associated with mammary glands of cows: genotyping to distinguish different strains among herds. Vet. Microbiol. 80:131-138.

Jørgensen, H. J., T. Mørk, D. A. Caugant, A. Kearns, and L. M. Rørvik. 2005. Genetic variation among Staphylococcus aureus strains from Norwegian bulk milk. Appl. Environ. Microbiol. 71:83528361.

Juhász-Kaszanyitzky, E., S. Janosi, P. Somogyi, A. Dan, L. van der Graaf-van Bloois, E. van Duijkeren, and J. A. Wagenaar. 2007. MRSA transmission between cows and humans. Emerg. Infect. Dis. 13:630-632.

Kaneko, J., and Y. Kamio. 2004. Bacterial two-component and heteroheptameric pore-forming cytolytic toxins: Structures, pore-forming mechanism, and organization of the genes. Biosci. Biotechnol. Biochem. 68:981-1003.

Kozytska, S., D. Stauss, M. C. Pawlik, S. Hensen, M. Eckart, W. Ziebuhr, W. Witte, and K. Ohlsen. 2010. Identification of specific genes in Staphylococcus aureus strains associated with bovine mastitis. Vet. Microbiol. 145:360-365.

McClure, J. A., J. M. Conly, V. Lau, S. Elsayed, T. Louie, W. Hutchins, and K. Zhang. 2006. Novel multiplex PCR assay for detection of the staphylococcal virulence marker Panton-Valentine leukocidin genes and simultaneous discrimination of methicillin-susceptible from -resistant staphylococci. J. Clin. Microbiol. 44:1141-1144.

McDougal, L. K., C. D. Steward, G. E. Killgore, J. M. Chaitram, S. K. McAllister, and F. C. Tenover. 2003. Pulsed-field gel electrophoresis typing of oxacillin-resistant Staphylococcus aureus isolates from the United States: establishing a national database. J. Clin. Microbiol. 41:5113-5120.

Middleton, J. R., L. K. Fox, J. M. Gay, J. W. Tyler, and T. E. Besser. 2002. Use of pulsed-field gel electrophoresis for detecting differences in Staphylococcus aureus strain populations between dairy herds with different cattle importation practices. Epidemiol. Infect. 129:387-395. 
Monday, S. R., and G. A. Bohach. 1999. Use of multiplex PCR to detect classical and newly described pyrogenic toxin genes in staphylococcal isolates. J. Clin. Microbiol. 37:3411-3414.

Moon, J. S., A. R. Lee, H. M. Kang, E. S. Lee, M. N. Kim, Y. H. Paik, Y. H. Park, Y. S. Joo, and H. C. Koo. 2007. Phenotypic and genetic antibiogram of methicillin-resistant staphylococci isolated from bovine mastitis in Korea. J. Dairy Sci. 90:1176-1185.

Neijenhuis, F., H. W. Barkema, H. Hogeveen, and J. P. Noordhuizen. 2000. Classification and longitudinal examination of callused teat ends in dairy cows. J. Dairy Sci. 83:2795-2804.

Piccinini, R., V. Borromeo, and A. Zecconi. 2010. Relationship between $S$. aureus gene pattern and dairy herd mastitis prevalence. Vet. Microbiol. 145:100-105.

Piccinini, R., L. Cesaris, V. Daprà, V. Borromeo, C. Picozzi, C. Secchi, and A. Zecconi. 2009. The role of teat skin contamination in the epidemiology of Staphylococcus aureus intramammary infections. J. Dairy Res. 76:36-41.

Pinto, B.. E. Chenoll, and R. Aznar. 2005. Identification and typing of food-borne Staphylococcus aureus by PCR-based techniques. Syst. Appl. Microbiol. 28:340-352.

Resch, G., P. François, D. Morisset, M. Stojanov, E. J. Bonetti, J. Schrenzel, O. Sakwinska, and P. Moreillon. 2013. Human-to-bovine jump of Staphylococcus aureus CC8 is associated with the loss of a $\beta$-hemolysin converting prophage and the acquisition of a new staphylococcal cassette chromosome. PLoS ONE 8:e58187.

Sakwinska, O., M. Giddey, M. Moreillon, D. Morisset, A. Waldvogel, and P. Moreillon. 2011. Staphylococcus aureus host range and human-bovine host shift. Appl. Environ. Microbiol. 77:5908-5915.

Schlotter, K., R. Ehricht, H. Hotzel, S. Monecke, M. Pfeffer, and K. Donat. 2012. Leukocidin genes lukF-P83 and lukM are associated with Staphylococcus aureus clonal complexes 151, 479 and 133 isolated from bovine udder infections in Thuringia, Germany. Vet. Res. 43:42.

Shopsin, B., M. Gomez, S. O. Montgomery, D. H. Smith, M. Waddington, D. E. Dodge, D. A. Bost, M. Riehman, S. Naidich, and B. N. Kreiswirth. 1999. Evaluation of protein A gene polymorphic region DNA sequencing for typing of Staphylococcus aureus strains. J. Clin. Microbiol. 37:3556-3563.

Smith, E. M., L. E. Green, G. F. Medley, H. E. Bird, L. K. Fox, Y. H. Schukken, J. V. Kruze, A. J. Bradley, R. N. Zadoks, and C. G. Dowson. 2005. Multilocus sequence typing of intercontinental bovine Staphylococcus aureus isolates. J. Clin. Microbiol. 43:47374743.

Sommerhäuser, J., B. Kloppert, W. Wolter, M. Zschöck, A. Sobiraj, and K. Failing. 2003. The epidemiology of Staphylococcus aureus infections from subclinical mastitis in dairy cows during a "control" programme. Vet. Microbiol. 96:91-102.

Stutz, K., R. Stephan, and T. Tasara. 2011. SpA, ClfA, and FnbA genetic variations lead to Staphaurex test-negative phenotypes in bovine mastitis Staphylococcus aureus isolates. J. Clin. Microbiol. 49:638-646.

Sung, J. M., D. H. Lloyd, and J. A. Lindsay. 2008. Staphylococcus aureus host specificity: comparative genomics of human versus animal isolates by multi-strain microarray. Microbiology 154:1949-1959.

Syring, C., R. Boss, M. Reist, M. Bodmer, J. Hummerjohann, P. Gehrig, and H. U. Graber. 2012. Bovine mastitis: The diagnostic properties of a PCR-based assay to monitor the Staphylococcus aureus genotype B status of a herd, using bulk tank milk. J. Dairy Sci. 95:3674-3682

van Cleef, BA., DL. Monnet, A. Voss, K. Krziwanek, F. Allerberger, M. Struelens, H. Zemlickova, RL. Skov, J. Vuopio-Varkila, C. Cuny, AW. Friedrich, I. Spiliopoulou, J. Pászti, H. Hardardottir A. Rossney, A. Pan, A. Pantosti, M. Borg, H. Grundmann, M. Mueller-Premru, B. Olsson-Liljequist, A. Widmer, S. Harbarth A. Schweiger, A. Unal, and J. A. Kluytmans. 2011. Livestockassociated methicillin-resistant Staphylococcus aureus in humans, Europe. Emerg. Infect. Dis. 17:502-505.

van Leeuwen, W. B., D. C. Melles, A. Alaidan, M. Al-Ahdal, H. A. Boelens, S. V. Snijders, H. Wertheim, E. van Duijkeren, J. K. Peeters, P. J. van der Spek, R. Gorkink, G. Simons, H. A. Verbrugh, and A. van Belkum. 2005. Host-and tissue-specific pathogenic traits of Staphylococcus aureus. J. Bacteriol. 187:4584-4591.

Voelk, V., H. U. Graber, B. H. van den Borne, C. Sartori, A. Steiner, M. Bodmer, and M. C. Haerdi-Landerer. 2014. A longitudinal study investigating the prevalence of Staphylococcus aureus genotype B in seasonally communal dairy herds. J. Dairy Sci. 97:4184-4192.

Zadoks, R., W. van Leeuwen, H. Barkema, O. Sampimon, H. Verbrugh, Y. H. Schukken, and A. van Belkum. 2000. Application of pulsed-field gel electrophoresis and binary typing as tools in veterinary clinical microbiology and molecular epidemiologic analysis of bovine and human Staphylococcus aureus isolates. J. Clin. Microbiol. 38:1931-1939.

Zecconi, A., E. Binda, V. Borromeo, and R. Piccinini. 2005. Relationship between some Staphylococcus aureus pathogenic factors and growth rates and somatic cell counts. J. Dairy Res. 72:203-208.

Zecconi, A., L. Cesaris, E. Liandris, V. Daprà, and R. Piccinini. 2006. Role of several Staphylococcus aureus virulence factors on the inflammatory response in bovine mammary gland. Microb. Pathog. 40:177-183. 